DOI: https://doi.org/10.34069/RA/2021.7.04

Volumen 4, Número 7/enero-junio 2021

\title{
A proposal of reflection on English Grammar Teaching
}

\author{
Una propuesta de reflexión sobre la enseñanza de la gramática inglesa
}

Recibido: 27 de julio de $2020 \quad$ Aceptado: 25 de octubre de 2020

\author{
Autores: \\ Isael Gómez López ${ }^{13}$ \\ Yoel Pérez Sánchez ${ }^{14}$
}

\begin{abstract}
The present work poses a reflection with the English language teachers on the importance that should be awarded to grammar in the teaching and learning of this language. Without leaving aside the integrating character promoted by the communicative approach in the treatment of the leading skills and the insertion of the students in communicative situations that enables the practice in linguistic habits formation through the development of the different components that are part of the communicative competence, the author expresses some ideas and criteria on how the professorship can teach grammar by means of the abilities to speak and write in English, and not English only through grammar.

Cross grammar teaching from the leading skills- according to what is being analyzed by this author_ provides the tools and is the vehicle to carry out any communicative endeavor beyond the classroom. The author presents a system of exercises that show the transversal relationship of grammar with the leading skills. For the development of this work some methods were used such as: historic-logical, analysis-synthesis, inductive-deductive, systemic-structural-functional and the documentary revision. With the application of this grammatical proposal the students improved their speaking and writing skills, and their linguistic self-confidence was increased as well.
\end{abstract}

Key words: Proposal of reflection, grammar cross relationship, English teaching, leading skills, linguistic self-confidence.

\section{Resumen}

El presente trabajo propone una reflexión con los profesores de idioma Inglés acerca de la importancia que se le debe conceder a la gramática en el proceso de enseñanza y aprendizaje de esta lengua.

Sin apartarse del carácter integrador que promueve el enfoque comunicativo en el tratamiento de las habilidades principales y la inserción de los estudiantes en situaciones comunicativas que les permita ejercitar la formación de los hábitos linguiísticos a través del desarrollo de los diferentes componentes que integran la competencia comunicativa, el autor aborda diferentes ideas y criterios sobre cómo el docente puede enseñar gramática mediante las habilidades para hablar y escribir en inglés, y no inglés por medio de la gramática.

13 Lic. Idioma Inglés. Prof. Asistente. Master en Ciencias de la Educación CUM Guisa.Granma. Cuba. https://orcid.org/0000-0002-4180-764X

${ }^{14}$ Ing. Agrónomo. Prof. instructor. Master en Gestión Ambiental CUM Guisa. Granma. Cuba. https://orcid.org/00000003-2815-7838 


\section{AMAZONANAS}

La enseñanza transversal de la gramática desde las habilidades rectoras _ según lo analizado por este autor_proporciona las herramientas y es el vehículo para emprender cualquier empeño comunicativo más allá del aula.

El autor presenta un sistema de ejercicios que demuestra la relación transversal de la gramática con las habilidades rectoras. Para la realización de este trabajo se utilizaron los métodos históricológico, análisis-síntesis, inducción-deducción, sistémico-estructural-funcional y la revisión documental.

Con la aplicación de esta propuesta de reflexión gramatical se logró mejorar las habilidades de hablar y escribir en inglés, así como el incremento de la auto-confianza y seguridad linguística de los alumnos.

Palabras clave: Propuesta de reflexión, relación transversal de la gramática, enseñanza del inglés, habilidades rectoras, auto-confianza lingüística.

\section{Introduction}

The foreign language lesson is sustained on general didactic linguistic, pedagogical and psychological foundations which depict it as such.

Any approach, idea or suggestion to go far towards the qualitative enhancement of foreign language teaching should definitely focus on the lesson because it is the framework in which both leading actors of this moment play their role.

The two-sided character of the teaching-learning process is marked through a mutual interaction between the activity of teaching performed by the teacher, and by that of the students, that is learning.

The lesson is also a way to impinge upon the formation and development of the pupils personality. This is the gist of its pedagogical character.

In foreign language teaching is important that the teacher has a vast knowledge of the linguistic elements that characterize it. These are knowledge of a very special type, they constitute a means of activation of the consciousness in the ideas- forming process and its verbal expression through speech. González, R. (2009)

The writer of the article agrees with this well-known author at asserting that without the knowledge on the particularities of the language units and the speech, is impossible to develop an effective process of language mastery in a foreign language.

The acquisition of the grammatical structures contained in the syllabi is paramount to efficiently guide the learners`communicative unfolding, beginning with the connection among the leading skills that self- complement to be trained up.

The treatment given to the grammatical objectives of the many units of the syllabus should be approached from the four abilities, supported on the principles of Didactics, which feed the language teaching-learning process of a foreign language.

So the author's point of view relies on this hypothesis: if the foreign language teacher ensures a conscious and productive learning of the grammar items under a well-aimed didactical conduction and working jointly with the communicative skills, the learners will be able to speak and write English better than they used to. 


\section{AMAZÚNAS}

Therefore, the objective of this article is to reflect upon the importance of learning grammar through the acquisition of the main skills in English language teaching, beginning with high school seventh- graders in order to get a wider attainment of the oral and writing skills which would enable a sooner communication in this language.

Any attempt to maximize or minimize the role of grammar teaching may be noxious for the linguistic health of the ones who teach this foreign language, and yet worse it is for those that study and learn English, either as a way of communication or as a means of professional activity.

People deepen in the grammar of their native language by the aid of a specific subject or major at school or at college. In Cuba, it is studied by means of the Spanish Language subject.

Speaking correctly the mother tongue is not only a sign of culture, but also a sample of national pride as Cubans.

A large variety of the mistakes made by Spanish- speaking people as they speak or write is due to the lack of knowledge or faulty use of the grammatical elements. Needless to say that if second- language teachers are literally aware of this phenomenon concerning their own language, then why are not they going to do something to prevent this from happening in the foreign one while there is still time?

If such an elemental standpoint as this is disregarded by a good teacher of English, then the expectations of teaching and learning good English may be jeopardized.

\section{Theoretical Framework}

\section{About the English Lesson}

Klingberg. L. (1972) and Savin. N.V. (1976) claim that "A didactically well-structured lesson is based on certain principles constituting general aspects of the organizational and methodological teaching content that are originated from objectives and laws which objectively rule over them".

For a better understanding of the objective of this article, this author wishes to stress on some of these didactic principles- fully aware of the fact that they should not be split away, but seen as a unit.

-Principle of systemic character of learning:

Foreign language teaching is aimed at the mastery of the communicative activity in itselft and not to a determined amount of linguistic content. That what is presented, should be studied as a system in which the linguistic units and the principles related to the division of the teaching material and to the upkeep of its integrity in the students'consciousness are hierarchied.

Sistemic differences and similarities between two languages interacting in the learning process (the native and the foreign one) compel the teacher to make comparisons and analogies taking into account the relations of association in each language. This implies the inclusion of means that make possible the systemization of the contents: schemes, graphs, tables, charts, etc.

Principle of the conscious character of learning: implies the conscious assimilation and application of the knowledge acquired in such a way that the regularities of the linguistic material previously studied can be seen in new communicative situations. 


\section{AMAZONANAS}

An important postulation on the current methodology and psychology about the mastery of a foreign language in the verbal activity process is that it predetermines the general direction of this process, of the conscious assimilation of the material in the foreign language to its practice as an automatized linguistic habit and its transformation into communicative skills.

This author is in agreement with the idea that the conscious procedure is only effective when it is submitted to the daily practice on reading and oral expression with a correct selection, presentation and organization of the linguistic material. It is true that an excessive grammatical analysis can be harmful; however, it is worth noticing that such analysis should be properly graded so as not to lessen the influence of grammar in foreign language learning. This issue will be discussed in the next pages.

Principle of direct sensory perception: is the exposition of the linguistic material in the students consciousness through transparent models and concrete representations that help to establish the bonds among the phenomena under study and also enable a more lasting remembrance, and a better assimilation.

Principle of accesibility: it has to do with the criterion of easy/ difficult, simpleness/ complexity of the linguistic material being studied.

Principle of attainability: it is applied when the teacher creates the prior conditions for a faster comprehension of the system of contents to be taught and its immediate insertion in different communicative situations or speech acts.

Castellanos, D. (1999) and Rico, P. (2000) express that "learning is an interactive, participative and collaborative process whose essential characteristic is the activity of communication heightening reflection, evaluation and self-evaluation".

From a psychological point of view, the teacher needs to know the operating rules to work with the linguistic material and to use it in communication.

In this direction, the linguistic habits are considered as components of the communicative skills and constitute automatized linguistic operations. They are made up through the development of the skills and not separated.

It does not mean- in the author's criterion- that there may be some degree of ascendency of one skill over the others depending on the specific objective(s) to be accomplished.

Memory plays a significant role in foreign language learning. The teacher can prepare activities to train memory and use it as a resource to fix the vocabulary and the grammatical rules throuh didactic games. González, V et al, (1995) explains that "memory is the cognitive and psychical process that allows the fixation, conservation and subsequent reproduction of the previous experience and the reaction to signals and situations which have acted over us".

The teacher should consider the elements stated so far to forsee the didactical treatment of the linguistic material through well-aimed communicative activities beginning with the English lesson.

\section{About the English Grammar}

The grammatical item as a component of the linguistic material provides the student with the theory and practice of the key language structure by gradually developing their knowledge and linguistic habits thoughout the teaching levels where the English subject is taught. 


\section{AMAZÚNAS}

The philosophical foundations of didactical materialism do not describe the language as an isolated system, but as part of a wider social outlook which takes into consideration the relationship between language and society.

The role of communication has risen to heights never attained before and taken different forms and shapes, so the study of human society is inseparable from the study of language.

All social and cultural manisfestations are reflected in language and it is precisely through language that people come to know the reality inside and outside themselves.

In our days the English language has spread all over the world as an instrument of communication. The relations of English-speaking peoples with Latin American nations are constantly on the increase, chiefly in the fields of culture, sports, science and trade. studies.

That is the reason why English is being taught from elementary school up to postgraduate

In English teaching, the overall system of the language guarantees the maintenance of an effective communication. As an essential part of this system, English grammar supplies the framework which allows the language to relate sounds to meaning and meaning to words. It gives the tools to produce and understand meaningful sentences.

Being an international language for worldwide communication compels learners to understand and be understood in English. One determining factor to accomplish this purpose is guiding English language learning from a communicative conception aided by the cross-grammar teaching. Bandura, (1997) states that "if the teacher believes that his oral linguistic competence is limited, this perception affects his self-efficiency to speak English".

Grammar ought to be taught in context. Grammatical patterns are just a part of the linguistic competence, and this linguistic knowledge is necessary in day-to-day interaction. Widdowson HG takes as a premise that "the knowledge of a language includes both the grammatical meaning of sentences, that is usage; and their functional value, that is use".

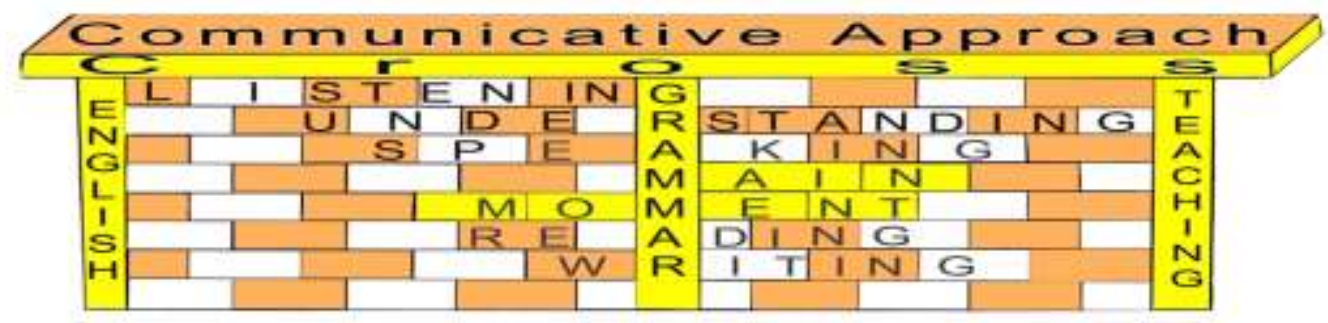

Figure 1. Comunicative approach

The reflection requested by the author regarding cross grammar teaching and its pertinency in English language learning can be exemplified by means of this house-shaped graph.

All the skills intertwine at some point of its treatment with the grammatical component. This connection should not be left behind for the sake of keeping up the integrality and functionality of the English teaching process.

Viewed from this transversal perspective, grammar is an upright-like post that fastens the common linguistic construction in which the skills dwell. They need this column to be safe and 


\section{AMAZỚNAS}

feel strong. But the grammatical basis cannot do much by itself; without its language mates, it would be of very Iittle use, speechless and unprotected as well.

So that grammar can feel alive and be helpful, it needs the skills which do have the spoken sounds of vowels and consonants or their combination, speech music and wording.

Uppermost there is the roof whose communicative sufficiency relies on the harmonic consistency of all its parts.

With all intention, the author includes the term understanding, not seen as a key skill but as a needful psychological process to accomplish an active communicative act.

The connection between grammar and the abilities in the English learning process is mediated -in the first place- by making a proper dosification of the type of information that is going to be presented to the students. "The teacher selects the material from the textbook, modifies it as needed, and presents it in such a way that its meaning in language be clear and memorable enough." Acosta (1999). According to this same author, this didactic implication is known as data input.

Secondly, the more the grammatical component and the leading skills are internally attached one to the others; bigger will be their relationship and reciprocal complementation.

Through the fixation stage the students make immediate use of the linguistic material that was dealt with. This is the right time for the intensive practice of the linguistic elements comprised in the communicative function. In the learning process this is called data intake.

Thirdly, along with the practice of the linguistic and communicative arsenal, there is also a spiral-like progress in communication. Such growth is certain when grammar and skills come forth together through a real communicative manifestation. This didactic implication has to do with the data output.

The author considers that in the English language teaching process, the teacher is continuously supplying new information due to some reasons to be taken into account while teaching such as: the psycho-pedagogical diversity of the group, the students' learning styles and their linguistic curiosity. This is the moment in which the teacher plays his role as a guide, a knowledge- provider, and a controller of the teaching activities.

In this cross-grammar teaching, the teacher should schedule a time space (main minute or main moment) as a reminder of the grammatical objective of the unit as he presents or practices the linguistic material (phonetical or lexical). Perfect occasion to solidify theory and practice, too. Acosta, R. (2005) asseverates that" when learning a language not only its grammatical system is acquired, but also its system in use, depending on the people, the location, the objectives, the modes of communication, among other factors of the context".

The layman terms used by this author in the explanation of the linguistic construction serve to decode the linguistic gears operating in foreign language learning.

For any English language learner - no matter the age- is easier to think of how a house is built up since it is better sensorially perceived than overwhelming him with a sophisticated exposition on the psychological aspects that take part in the learning process.

Making the students active participants in the construction of this house will commit them more profoundly with their own learning. 


\section{AMAZONAS}

To do the practical exercises the child needs to think how the language is used in responding to a given situation; sometimes he would play the role of a constuctor, a teacher, a bricklayer; or act out as if he runs into a foreign child. Enríquez O' \& Farrill, I. (2006), just to mention some examples. Logically, to succeed in adequatedly representing the communicative situations he needs to reveal his imagination, fantasy and creativeness.

If the teacher keeps in mind the before-stated didactic principles, he will be more likely to attain a higher communicative competence as well.

The author's experience as a teacher of English in all types of education and teaching levels allows him to allege that the observation of the so-called cross grammar is pertinent if it is approached like it has been portrayed so far - right in the middle.

Furthermore, there are other benefits (already seen at Ernesto Guevara Language School) of which the students can take advantage, in case the professorship makes this suggestion their own:

1. It raises the students' linguistic and communicative self-assurance for they feel more secure at speaking or writing since grammar-related mistakes or misinterpretations are lesser. It is a fact that at some point they might need help regarding lexicon supply at the time of speaking about a certain topic, but it would not stop the communicative performance. The teacher should encourage the conformation of strategies headed to solving learning tasks, vocabulary, linguistic patterns, pronunciation, speaking, listening, reading comprehension and writing, as those suggested by Pulido Diaz, A. (2005).

2. Cross grammar reinforces the principle of the sistemic character of teaching inasmuch as the student realizes the intra-connection among all the lessons of the unit, being the grammatical bridge the linking element.

Take, for instance, the forms of the verb BE in present (am, is, are); if the learner fixes this pattern, then automatically he will be able to use it in context through practice.

This linguistic habit is indispensable to efficiently produce conversational- like situations concerning these communicative functions: greeting, asking and telling the time, asking and giving personal information (name, age, telephone number), nationalities, occupations, and some others.
A: How are you?
B: I am fine.
A: How is your brother Frank?
B: He is O.K.
A: What time is it?
B: It is 10.05 a.m.
A: What is your name?
B: My name is.............. I am.

A: What are their jobs?

B: They are carpenters. unit.

Every time the teacher gives a lesson, he would dwell on the grammatical point of the 


\section{AMAZÖNAS}

Therefore, this is not a matter of adding isolated contents, one unplugged from the others; but integrating those linguistic units towards a common objective: the mastery of the communicative activity.

It is said that grammar learning is not the end in English- language teaching; however, if it is not consciously taught- at least through the skills- then it will hardly become the means that is meant to be.

3. The cross-grammar approach stands out the learners` role as leading actors of their selflearning performance for they turn themselves into the active doers of the speaking and writing tasks.

A comparative study (grammar only) on the learning outcome in the students of fourth and first level from the Language School in Guisa shows how the grammatical mastery is gradually on the increase in both the oral and the written component.

\section{Table 1.}

Comparative data.

\begin{tabular}{|l|l|l|l|l|}
\hline AVERAGE & MID TEST & FINAL TEST \\
RESULT & Oral (15 pts) & Written (7 pts) & Oral (15 pts) & Written (7pts) \\
\hline 4th level & $13.5 \%$ & $6.2 \%$ & $13.8 \%$ & $6.6 \%$ \\
\hline 1st level & $14.3 \%$ & $6.1 \%$ & $14.4 \%$ & $6.3 \%$ \\
\hline
\end{tabular}

This grammatical treatment favors the students with the suitable tools to carry out any communicative endeavor outside the classroom walls.

The teacher should teach the students HOW to use the grammar items for the betterment of their speaking and writing skills; namely, they need to know WHERE the patterns come from and HOW they are used in context. The mastery of only grammatically correct sentences means nothing unless they are aimed at a functional and communicative purpose.

What is all about is teaching grammatical patterns instead of rules that can be easily forgotten as the students express themselves. This is where the linguistic habits plus the irreplaceable role of the leading skills come on stage through drills and practice.

It is important to keep in mind WHAT grammar to teach, to WHAT type of students, WHEN and HOW.

So that a good practice on listening, speaking and reading can exist, it has to be grammatically seasoned.

This cross grammar view is particularly fruitful when an English language learner is asked to aid another one in solving a class assignment at home, helpless the teacher's assistance. Vigotsky (1987) states that "the intra-psychological area is characterized by the alreadyestablished subjectiveness what expresses the current development or effective development attained at a determined moment, that is, what the student can do by himself."

Let's take another example with the simple present tense to deal with functions expressing likes and dislikes, giving directions, or talking about daily activities. There are some distinctive features touching the formation of this structure. 


\section{AMAZÓNAS}

-The pronunciation of $-\mathrm{s}$, -es of the verbs in third person singular,

-The spelling rules for adding $-\mathrm{s}$ or -es to the verbs,

-The time expressions,

-The formation of info-questions,

-The use of the auxiliares DO or DOES in negative and interrogative sentences,

-The emphatic use of DO or DOES in affirmative sentences.

A: Where do you live?

B: I live in Cuba.

A: Where does Peter work?

B: He works in a school.

A: What kind of music does Rose like?

B: She likes romantic music.

It is the teacher's task to provide the necessary explanations and the sufficient variety of activities to make the students be able to identify the pronunciation of $-\mathrm{s}$ (He works hard); - $\mathrm{z}$ (She plays the piano); -iz (Miriam misses her sister) as they listen to a given material or, to produce them as they speak or read. Likewise, the student should be aware of the correct spelling of the verbs ending in $-\mathrm{y}$, or as they write a sentence in third person singular (carry-carries; go- goes, etc).

The teacher of English should bring into play his pedagogical mastership to arrange the treatment of these grammatical features at the cross point with the skills. Lafayette (1993) and Lange (1990) assert that "the communicative competence has the leading role, seconded by the didactic competence to teach the language". Lange (1990) alleges that "the language sufficiency implies the teacher's skill to understand, read, speak and write in the language he teaches".

What has been stated insofar does not mean that all teachers have forgotten about the role of grammar in English teaching, but if there is any doubt about the importance of this reflection, suffice it to recall the amount of time spent by the students in learning English from elementary education up to high school or college, and not always the communicative outcome in this language is the expected one.

It is a truth that English is not the only subject that the students learn throughout the different teaching levels, what demands a careful distribution of the study time devoted to each matter. So it is the teacher's concern to make the students see English not just as a subject- which for a great many of them is to be passed in one way or another- but as a second language, as a challenge to the unknown. Brosh (1996) claims that among the most important characteristics of an efficient teacher are the communicative competence and the skill to organize, explain and keep up the students' interest and motivation.

The author of this article sums up his points of view and criteria about cross grammar teaching on the idea that it is the coherently graded treatment of the grammatical material whose theoretical mastery and practical use is reinforced through the leading skills so as to attain a more solid communicative sufficiency.

\section{About the Exercises to Practice Cross Grammar}

This part of the article covers the practical manifestation of cross grammar teaching through oral and written exercises from the communicative skills. Antich et al (1986) defines that "exercising in foreign language is the repeated accomplishment of actions aimed at the assimilation of such actions, based on the comprehension and accompanied by a corrective and conscious control". 


\section{AMAZONANAS}

Richard, J. C and Lockhart, Ch. (1995) highlight these sequencing activities in foreign language teaching:

- Pre-communicative activities: based on activities focused on the presentation of structures, functions and vocabulary.

- Communicative activities: based on activities focused on the part of the information and exchange of information.

This author takes into account some practical aspects for the preparation of the activities presented in this section and some types of exercises suggested by Cancio, RG. (2009).

The degree of complexity of these exercises varies from one to another. It is up to the teacher to use them all, or to make his own choice, according to the teaching level and the degree of development of the students' communicative skills, among other elements.

The main purpose is to exemplify how to conceive a coherent treatment of the grammatical component (the simple present tense- in this case) through the leading skills.

1 Listening exercises.

1 Read this title of an excerpt you are going to listen to.

"Why we must fight the destruction"

- Is this a question? What kind of destruction is the excerpt going to speak about?

- Listen to the excerpt and complete the blanks with the words from the list.

LIST: affect, contain, clear, threaten.

When people and burn rainforests millions of tons of carbon dioxide go to the atmosphere and they ---------- the climatic conditions and severe flooding, drought, and crop failure. The rainforests ------------ at least half the Earth's species.

- $\quad$ Tick the correct information according to what you have listened to.

---- At the current rate of devastation, around 50 species will become extinct every year.

---- At the current rate of devastation, around 15 species become extinct every day.

- Grammar exercises.

Why we must fight the destruction.

When people clear and burn rainforests millions of tons of carbon dioxide go to the atmosphere and they affect the climatic conditions and threaten us all with severe flooding, drought, and crop failure. The rainforests contain at least half the Earth`s species. At the current rate of devastation, around 50 species become extinct every day. If this destruction continues, only nine of the 33 countries currently exporting rainforest timber will have any left by the end of the decade.

Please, help us save the tropical rainforest now, before it's too late.

(Taken from the English Workbook for seventh graders).

- $\quad$ Find in the previous text all the verbs in simple present tense. 


\section{AMAZÖNAS}

- Underline one sentence in third person singular. How did you recognize it?

- How can you form the third person singular of the verbs you found in ítem 2.1.?

- Group the verbs according to the pronunciation of $-\mathrm{s}$, -es ending in the third person singular.

/s/ lz/ liz/

- $\quad$ Make the first affirmative sentence negative.

- Ask and answer this question with your partner based on the information provided in the fourth sentence of the text.

Follow this model: What happens if........?

- Translate the fourth sentence into Spanish.

- $\quad$ Tell your partner what you do to stop the deterioration of the environment.

- $\quad$ Ask her / him what actions she or he does not do to contaminate it.

3 Speaking exercises.

3.1 Read this situation based on the text in exercise 2 .

Three classmates meet after reading a report on the destruction of the rainforests. Complete the gaps. Then act out the conversation.

Cinthya: Interesting report, isn't it?

Richard: Yes, indeed.

Susan: So, when people ------------ rainforests, carbon dioxide to the

Cinthya: And it also ------------ the ------- conditions.

Richard: That's why severe -------------, ------------- and crop --------- may --- us all.

Susan: Definitely, we must help ------------ the -------------- rainforests.

Cinthya: Sure. You can count on me.

Richard: When do we start?

3.2 Give your opinion about the text.

3.3 Create a similar dialogue using the synonym of these verbs:

Affect: influence over.

Threaten: menace.

Contain: comprise.

Continue: go on.

Save: preserve.

Burn: destroy.

Become: turn into.

- $\quad$ Reading exercises.

4.1 Repeat the following sentences after the teacher:

At the current rate.

“ " “ " “ of devastation,

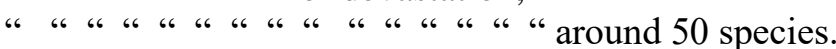

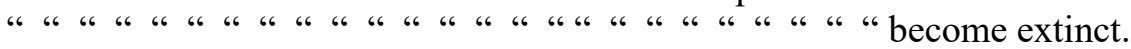

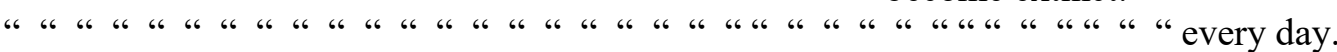

4.2 Answer the following questions about the text:

4.2.1 What happens when many persons burn rainforests? 
4.2.2 How does it influence over the weather conditions and over the people?

4.3 Read the text once more (observe the pronunciation, liaisons and intonation of $-\mathrm{k}$ in clear, contain, continue; - $v$ in save; - $p$ in help.

4.4 Translate the text into Spanish. (TBHI).

5- Writing exercises.

5.1 Provide other verbs that express what we should do to protect the environment.

5.1.1 Write five sentences to illustrate their meaning.

5.2 Add more topic- related information to the text.

5.3 Make an overall exposition of the text based on a plan of your own.

\section{Conclusions}

The development of any ability involves the mastery of vocabulary, grammar and phonetics items. Grammar mastery in the sense of knowledge and use of the verb tenses is crucial in the English Language learning process.

This work covered the main requirements for shaping up the English lesson from a psychological, didactical and pedagogical view.

The teaching-learning process establishes some personal relationships either among the students by themselves or between the teacher and the students. In the latter, the teacher's role is lofty anew as to the explanation, selection, grading and drilling of the grammatical component so that the learners understand and use it in a fluent communicative performance.

The teacher's example as a good communicating being in the language, he teaches ought to turn into a triggering element to motivate and encourage the students to speak English properly.

Cross grammar teaching through the key skills according to what has been exposed by this author contributes to enliven the English language teaching. This is the point of this reflexive proposal. At an earlier stage beginner learn some expressions formulaically in case they need to carry out a given communicative task, but the author's intention is to further stress on the examination, practice, expansion and recycling of the grammatical structures learned (as shown in 1.3) to thus become the students the truly actors of their self-learning activity.

\section{Reference}

Acosta, R. (2005). Didáctica desarrolladora para lenguas extranjeras. La Habana: IPLAC.

Acosta, R., Rivera Pérez, S, J., Pérez García, J. E. y otros (1999). A Communicative Language Teaching. Newcastle, New South Wales: Sumptibus Publication.

Antich de León, R. et al. (1986). Metodología de la enseñanza de lenguas extranjeras. La Habana: Ed. Pueblo y Educación.

Bandura, A. (1997). Self-efficacy: The exercise of control. New York: W. H. Freeman Company.

Brosh, H. (1996). Perceived and characteristics of the effective language teacher. Foreign Language Annals, 29(2), 125-138.

Castellanos, S.D. (1999). La comprensión de los procesos del aprendizaje: apuntes para un marco conceptual, Centros de Estudios Educacionales, ISP E. J. Varona, La Habana.

Enríquez, O’ \& Farrill, I., \& Pulido, A. (2006). Un acercamiento a la enseñanza del inglés en la Educación Primaria. Ciudad de La Habana: Ed. Pueblo y Educación.

Cancio, R.G. (2009). La clase de Lengua Extranjera. Teoría y práctica. Ciudad de La Habana: Ed. Pueblo y Educación.

González M.V., Castellanos, D., Córdova, M.D, y otros. (1995). Psicología para Educadores. La Habana: Ed. Pueblo y Educación. 


\section{AMAZONAS}

Klingberg, L. (1972). Introducción a la didáctica general. La Habana: Ed. Pueblo y Educación.

Lafayette, R. C. (1993). Subject matter content: What every foreign language teacher needs to know. En: G. Guntermann (comp.), Developing language teachers for a changing world (pp. 124-158). Chicago: National Textbook.

Lange, D. L. (1990). A blueprint for a teacher development program. En J.C. Richards y D. Nunan (comps.), Second language teacher education (pp. 245-268). Cambridge, MA: Cambridge University Press.

Pulido, A. (2005). Propuesta de estrategia didáctica desarrolladora, para concebir el proceso de enseñanza- aprendizaje de la competencia comunicativa integral de la lengua inglesa, en alumnos de 6to grado de la escuela primaria en Pinar del Río. (Tesis en Opción al Grado Científico de Doctor en Ciencias Pedagógicas), Instituto Superior Pedagógico Rafael María de Mendive, Pinar del Río.

Richard, J. C. y Lockhart, Ch. (1995). Reflective Teaching in second Language Classrooms (second printing). Cambridge University Press.

Rico, P., y otros. (2000). Algunas consideraciones teóricas de carácter general para la operacionalización de las variables "Proceso de enseñanza- aprendizaje" y "Aprendizaje desarrollador". ICCP.

Savin, N.V. (1976). Pedagogía. La Habana: Ed. Pueblo y Educación.

Vigotsky, S. (1987). Historia del desarrollo de las funciones psíquicas superiores. La Habana: Ed. Científico- Técnica. 